\title{
ANALYSIS OF URBAN FORM AND INFRASTRUCTURE IN PALEMBANG
}

\author{
Johannes Adiyanto ${ }^{1}$, Setyo Nugroho ${ }^{2}$, Adhika Atyanta ${ }^{3}$ \\ 1,2. Architecture Department, Engineering Faculty, Sriwijaya University, \\ Jl. Raya Prabumulih KM 32, Inderalaya 30662, Indonesia \\ 3. Stupa Architama, J1. Masjid Al-Hijrah 3906 RT.32 RW.09 Kel. Demang Lebar Daun, \\ Palembang, Indonesia \\ Email: johannesadiyanto@ft.unsri.ac.id
}

\begin{abstract}
Analysis of physical characteristics of urban, which called urban form, can identify the shape, size, density, and configuration of settlements, which considered at the different scale: from regional to urban. In the different perspective, transportation shapes the cities. Based on these two concepts, this paper analyzing the growth of Palembang based on their infrastructure, especially transportation. This paper using the chronicles and narratives method with strategic overlay maps. The maps were arranged based on the years chronically and then analyzed the transportation infrastructure in that years. The results of this analysis, Palembang already growth based on the land transportation. The natural potential, the Musi River, was ignored. The main street, Jendral Sudirman street, become the 'backbone' of Palembang.
\end{abstract}

Keywords: urban form, transportation, chronicles, and narratives method, Palembang.

\begin{abstract}
Abstrak
Judul: Analisis Bentuk Urban dan Infrastruktur di Palembang

Analisis kareteristik fisik urban, yang biasa disebut dengan bentuk urban, dapat mengidentifikasi bentuk, ukuran, kepadatan, dan konfigurasi hunian, yang mempertimbangkan berbedaan skala, dari region / wilayah, hingga urban/ kota. Disisi lain, transportasi juga membentuk wajah kota. Dengan dasar dua konsep tersebut, kertas kerja ini menganalisis perkembangan kota Palembang berdasarkan infrastrukturnya, terutama infrastruktur transportasi. Metode yang digunakan adalah metode kronologis dan naratif dengan strategi 'penumpukan' peta. Peta-peta akan disusun berdasarkan tahun-tahun secara kronologis dan kemudian dianalisa infrastruktur transportasinya dari tahun ke tahun. Hasil analisis bahwa Palembang sudah berkembang berdasarkan infrastruktur darat. Potensi alami, yaitu Sungai Musi, telah diabaikan. Jalan Jendral Sudirman menjadi 'tulang punggung' utama dari Kota Palembang.
\end{abstract}

Kata kunci: bentuk urban, tranportasi, metode kronologis dan naratif, Palembang.

\section{Introduction}

Palembang is one of the oldest city in Indonesia. In past time, Palembang develops based on the Musi river. There were many important places in the kingdom era or old kampong located at Musi riverbank. This situation also happened when many oil companies build their refinery and dwelling area. Musi river becomes an important infrastructure in that time. That's why Palembang have another name: "The Venice from the East". (Van Sevenhoven, 2015). In this paper, Sevenhoven description is the basic knowledge and situation of Palembang. This paper also uses Anderson study as background theory of urban form. He said that: "urban form may be defined as the spatial configuration of fixed elements within a metropolitan region. 
This includes the spatial pattern of land uses and their densities as well as the spatial design of transport and communication infrastructure". (Anderson, Kanaroglou, \& Miller, 1996). This paper describes the transformation of urban form of Palembang from 1910 - 2010 based on Nugroho study (Nugroho, 2012) and added the latest study between 2010 until 2017.

Palembang has many stages of urban development. Sevenhoven description above is based on a royal period when Palembang become the capital city of Palembang Darussalam. After that, Dutch came and make an urban city plan of Palembang, especially around the 1930's. After that Palembang have no progress of urban development until Ampera Bridge constructed. That's bridge connected between Ilir and Ulu side of Palembang. Ampera bridge already planned from the Dutch era, but after Indonesia independence, that bridge can be built with money from war reparation. There was no special development during $1970-2003$. At 2004, Palembang became the host of national sports event called PON. There was massive development at Ulu side, around Jakabaring area. Today called Jakabaring Sports City. After that, there were several sports event, national or international. One of the consequences of that development, from 2010 until 2016, the population of Palembang increase constantly.

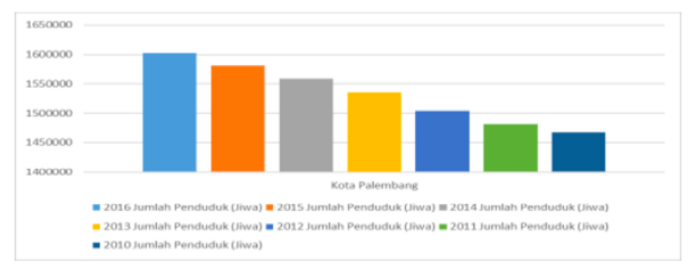

Figure 1. Palembang population Source: https://palembangkota.bps.go.id/
Lynch said that "A city is the characteristic physical and social unit of civilization. It possesses the size, density, grain, outline, and pattern. The people who live in it shape these properties and are shaped by them" (Danilo S. Furundzic; \& Furundzic, 2012). Based on Lynch statement, this paper wants to look the urban form transformation and also the movement of the citizen which can look with the development of infrastructure. There is any closed relationship between a social unit of civilization (urban housing) and also the physical unit like road or transportation infrastructure.

\section{Urban Form}

Anderson described that there were three simple archetypal of urban forms: the concentric city, the radial city, and the multinuclear city. (see Figure 1).

In another perspective, there is any relation urban form, economic growth, and infrastructure. Bruinsma said that general factor like technology, demography, economy and environmental and public policy can shape a wider context of the relationship between transport infrastructure and the spatial pattern of economic activities. (Bruinsma, Rienstra, \& Rietveld, 2013). In this paper show the link between urban form and transport infrastructure as the urban shape of Palembang. 


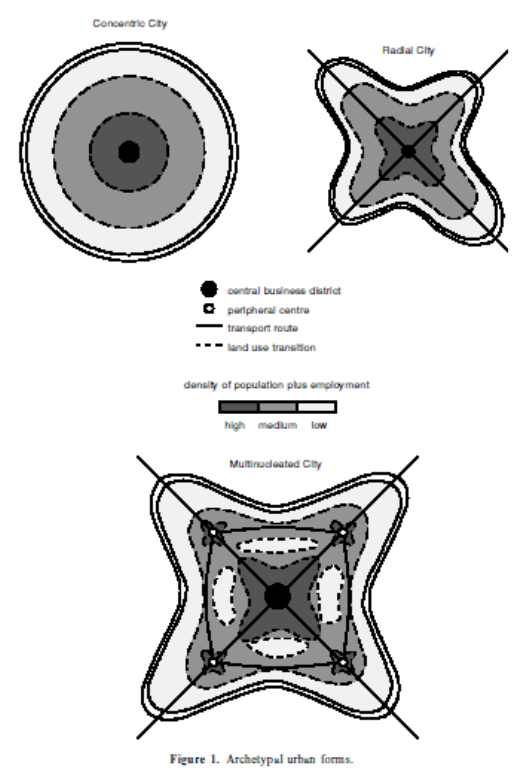

Figure 2. Archetypal of urban form Source: Anderson et al.,1996

\section{Urban Infrastructure}

Infrastructure is vital to the creation of sustainable cities, and proper planning is vital to the creation of sustainable infrastructure. (Neuman, 2012). Infrastructure, especially transport infrastructure, shapes cities. Transportation is a derived need, meaning that people typically travel for some purpose other than for the simple reason of traveling (Trubka, Newman, \& Bilsborough, 2010). From 20112014, Palembang city transport growth $3-5 \%$ per year comprise of passenger transportation, buses, truck, motorcycle and special vehicle. (Noftri, Faizal, \& Mohadi, 1999).

Based on that previous exegesis, there is a question what the transformation of urban form in Palembang city? Is it have a link between physical urban structure and their roads? There is the main problem to be showed in this paper.

\section{Methodology}

The method based on historical research perspective, with chronicles and narrative inquiry method and using overlay maps strategic. Another definition of the overlay is an analysis procedure for determining the spatial coincidence of geographic features. The overlay function output is capable of creating composite maps by combining diverse data sets. (Yenigun \& Ecer, 2013).

Nugroho already did urban morphology of Palembang during 1910 - 2010 and used chronical maps (Nugroho, 2012). From 2010 - 2016, this paper using remote sensing data and GIS analysis. Remote sensing techniques allow taking images of the earth surface in the various wavelength region of the electromagnetic spectrum (EMS). One of the major characteristics of a remotely sensed image is the wavelength region it represents in the EMS. Some of the images represent reflected solar radiation in the visible and the near infrared regions of the electromagnetic spectrum, others are the measurements of the energy emitted by the earth surface itself. (Aggarwal, 2004).

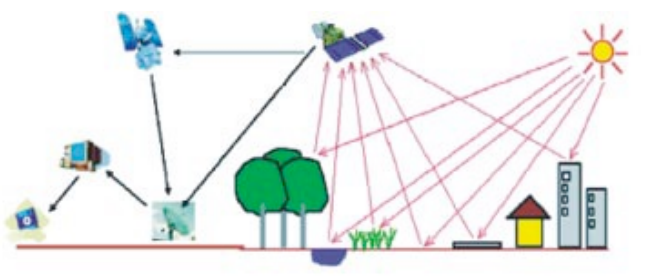

Figure 3. Remote sensing process Source: Aggarwal, 2004

\section{Results}

Based on Nugroho studied, in the past, urban patterns of the study area used to be tied to the logic of the watershed, with water being one of the most important factors. The built-up area, 
mostly dwelling, was growing alongside the river banks and stretched not far inland following the watercourses, and transport was principally carried out by ship. (Nugroho, 2012)

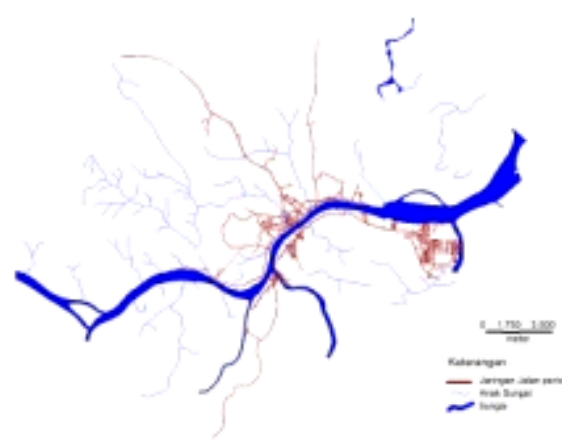

Figure 4. Palembang around 1910 until 1930 Source: Nugroho, 2012

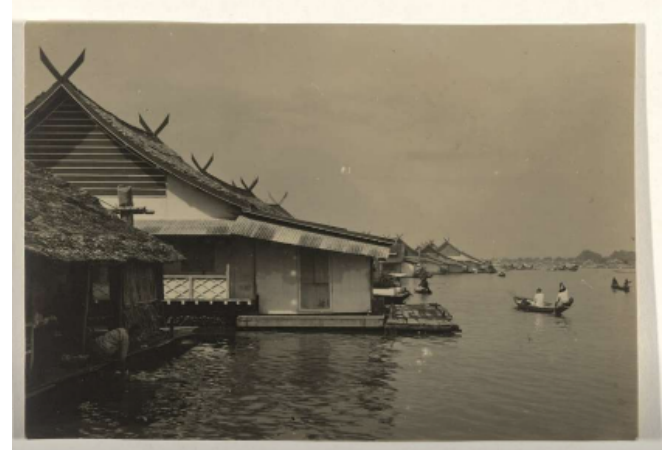

Figure 5. Floating houses in Musi River Source:

https:/www.rijksmuseum.nl/en/search/objects $? \mathrm{q}=$ palembang $\& \mathrm{p}=6 \& \mathrm{ps}=12 \& \mathrm{st}=$ Objects $\& \mathrm{ii}=6$ \#/RP-F-2012-106-27-1,66

Tufek-Memisevic said that the idea of linearity was expressed by emphasizing the main transportation route as the backbone of the proposed urban layout. All other functions were arranged along that axis with a defined width and indefinite length, intersected at certain intervals by secondary perpendicular streets. (TufekMemisevic \& Stachura, 2015). In Palembang case, Musi River becomes a main 'road' based on the map from 1910 until 1930.
The urban road network was first built during the colonial era and initially constructed by considering watercourses. (Nugroho, 2012). Dutch also build Talang Semut area as their dwelling. This area is not located at the river bank of Musi river but located in a 'dry' land.

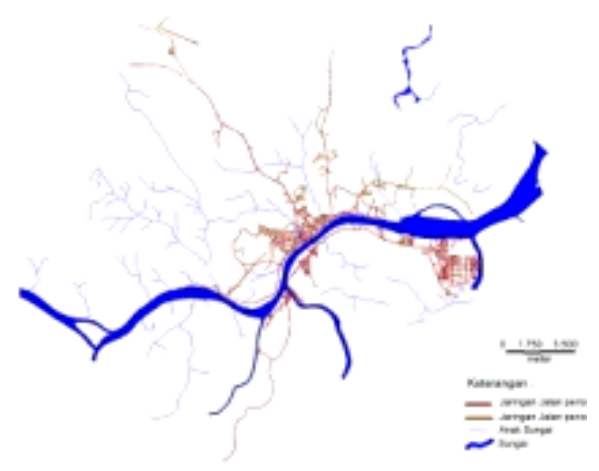

Figure 6. Palembang around 1930 until 1950 Source: Nugroho, 2012

In this era, Palembang still dominated by waterfront culture. The Dutch dwelling at Talang Semut was a new urban housing in that time. For developed that area, they hoard the Tengkuruk river.

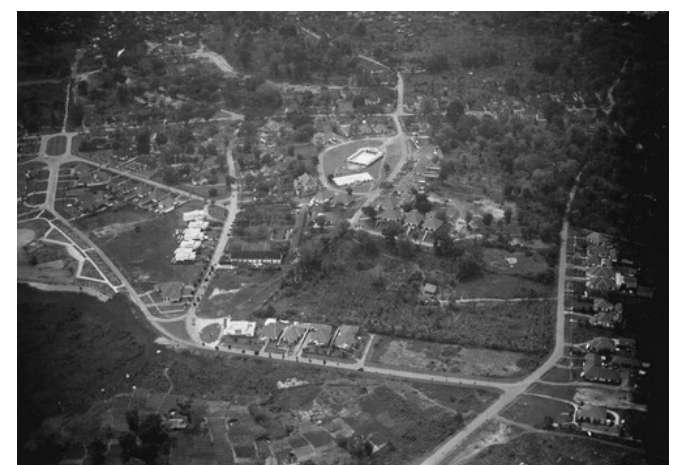

Figure 7. Aerial photo of Talang Semut Source:

https://collectie.wereldculturen.nl/\#/query/d9f8 bcfe-54d8-47b9-8f40-b782565fd7dd

Figure 7 showed that housing constructed in 'dry' land, not in a river bank like before. 
The built of the bridge over the Musi river at the 1960s gave a big influence on the area development and increasing the accessibility of study area. The river is no longer functions as the transportation mode. (Nugroho, 2012). The idea of making a bridge had been started since 1924 when the mayor of Le 'Cocq de'Armadville, but because The Dutch government did not have a money to construct that bridge, the plan only plans during the Dutch occupation. Finally, in 1961 the construction of the bridge begun and finished after 41 months. The Inauguration of the Bridge was precisely 10 November 1965 and was given the name Bung Karno Bridge, and in 1966 the name changed to become 'Ampera' Bridge. (Santun, 2001).

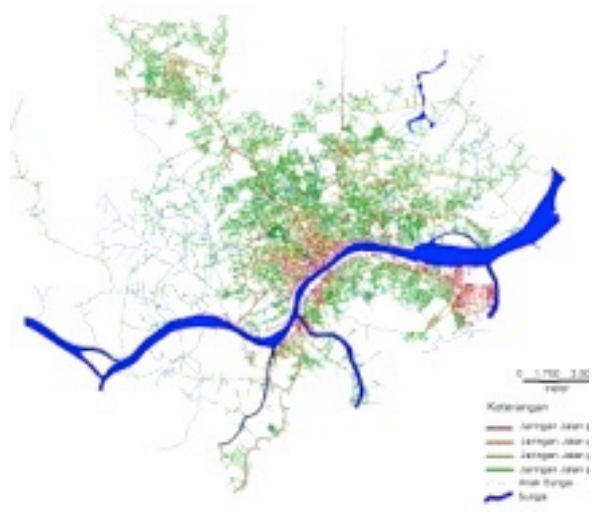

Figure 8. Palembang around 1970 - 1990 Source: Nugroho, 2012

Ampera Bridge changing the culture for Palembang citizen, their use more car than a small boat. The road becomes the main infrastructure to move from one place to another. Before this bridge constructed, Japanese already built a 'long' road from Pasar 16 district to airport at Talang Betutu. This road, right now, called Jalan Jendral Sudirman.

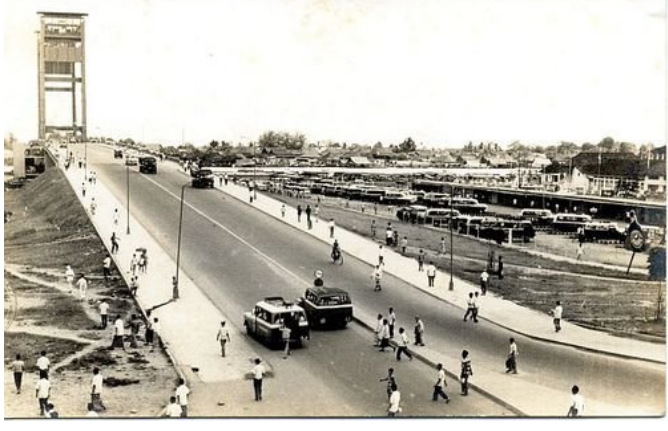

Figure 9. Ampera Bridge around the 1970s Source:

http://palembang.tribunnews.com/2017/10/17/ berikut-bebeapa-fakta-sejarah-berdirinyajembatan-ampera-sebagai-lambang-kotapalembang?page $=$ all

As result, Nugroho said Lowland area in the center of Palembang is already highly urbanized, the urban problems requiring innovative and more locally adapted solutions. The needs for development in flood-prone urban areas are generally justified by the areas needed for living and other social economic development. However, the dynamic land use changed processes that occurred in the area may result in disordered that give some negative influences on the development of the city. (Nugroho, 2012). Based on his study, this paper continues that studies, use another method. We use remote sensing data and GIS analysis. In 2001, this the result:

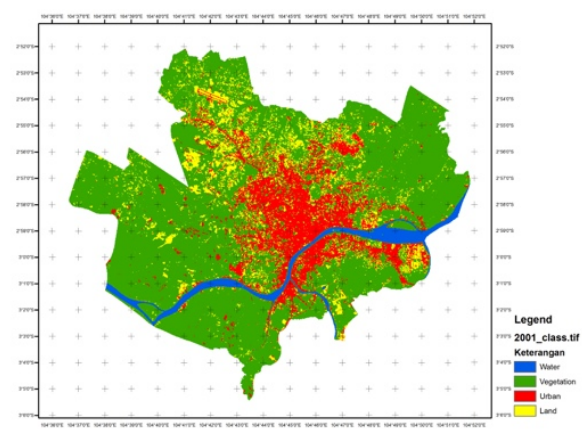

Figure 10. Palembang map in 2001

There was no significant urban form transformation compare with a map of Palembang in 1990. In 2004, 
Palembang becomes the host of PON XVI (national sports event), and the government built new sports facilities at Jakabaring area, in a south of Palembang city. This is the map situation in 2007 :

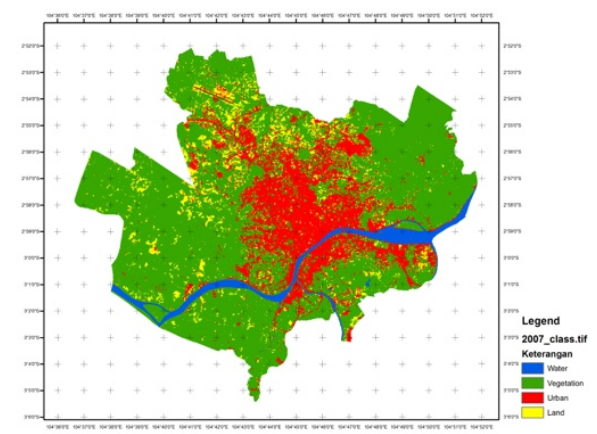

Figure 11. Palembang map in 2007

There were many supporting sports facilities like housing for the athlete and many more. Jakabaring before national sports event only an empty swap area.

After national sports event, Palembang also conducted as host of South East Asia sports event called SEA Games in 2011. In August 2018, Palembang and Jakarta become the host of Asia Sports Event called Asian Games. This is the map which shows the condition of the urban form of Palembang in 2016.

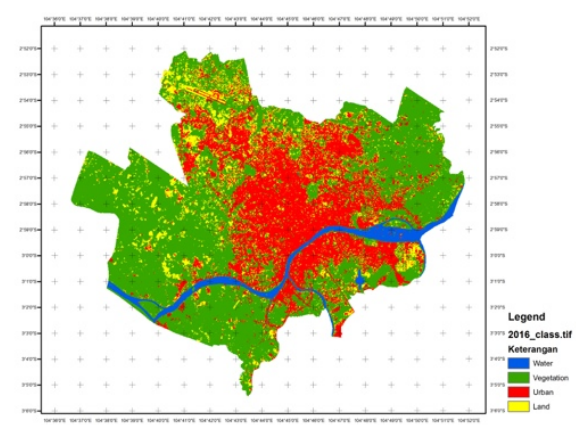

Figure 12. Palembang map in 2016

The urban form of Palembang run into the multinuclear city from the linear 'traditional' city. During 1910 until before constructed of Ampera Bridge,
Palembang still the linear city, based on Musi river. After Ampera Bridge built and operation, Palembang change to become the radial city because there were two 'main' infrastructures for moving of citizen, based on the river and based on the road. After Jakabaring sports city built around 2004, Palembang growth fast. Jakabaring.

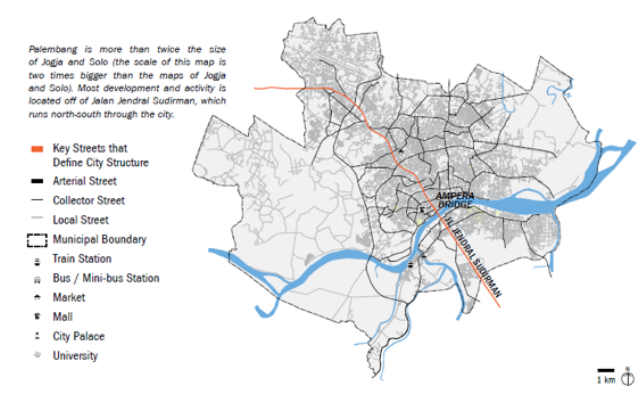

Figure 13. Jalan Sudirman become the main road of Palembang (2011 condition) Source: CDIA, 2011

Right now, Jakabaring become the one of compact urban in Palembang, because that district has a private housing, modern economic facilities like a modern shopping mall, hotel, offices - and recreation facilities.

From 2001 until 2016 we can see the increasing urban area, and decrease of vegetation one. This is the consequences of urban development.

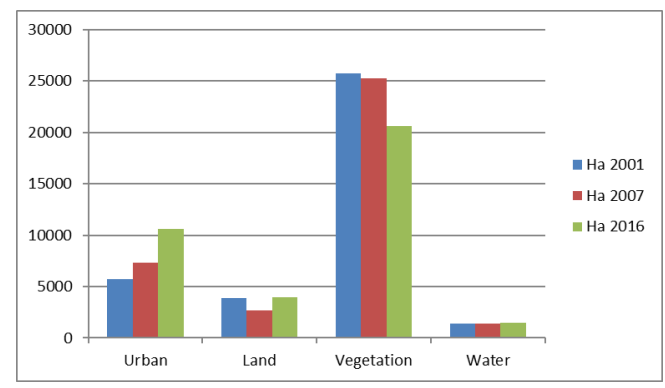

Figure 14. Comparation table of Palembang condition during 2001 until 2016

\section{Discussion}

That result which already describes previous, show us that Palembang has 
to change of urban form because of the development of infrastructure and sports facilities. But the problem is the infrastructure for citizen mobility less than housing growth. Palembang still based on 2 type mobility infrastructures, based on river and roads. The main road of Palembang, from the 1960s until now, still Jalan Jendral Sudirman, and that road capacity become higher because of citizen mobility based on the car not based on mass transportation. This condition is like a time bomb of bad traffic jam in Palembang.

The government builds Light Rail Transit (LRT) in 2017 until 2018 for supporting the Asian Games, a sports event for Asia region. The LRT goes from the airport to Jakabaring Sports City, and the final station in OPI, modern shopping mall for support sports facilities. The problem is that LRT only have one corridor and build upper side of Jalan Jendral Sudirman. This is the sum of all mass transport in Palembang in 2018 condition:

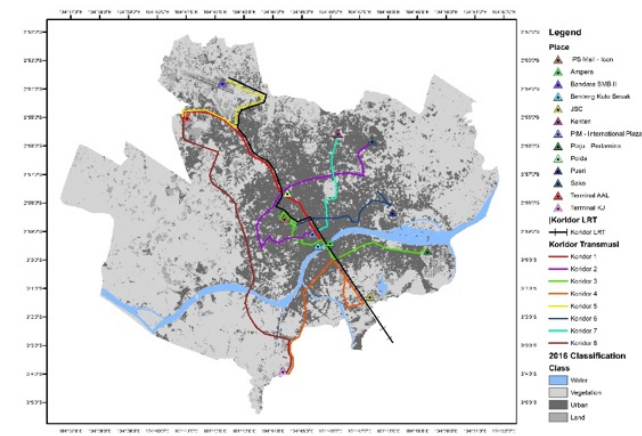

Figure 15. Urban form of Palembang and the public transport network

The integrated transport network is one of the solutions for the potential of traffic jam in Palembang. The transport network is not only based on the road but also on the river.

Another solution in urban form perspective is the compact city. The compact city is most likely to be brought about by intensifying existing urban areas - increasing densities, activity and the mix of uses - and by attracting people back into the city. For this to be viable, two conditions need to be satisfied: compacting the city must be a profitable activity for the producers of the built environment (the developers and funding institutions); and, as a key determinant of the first condition, the compact city must be an attractive location for the consumers of the built environment (residents, employers, service suppliers and so on). (Jenks, Burton, \& Williams, 1996).

Palembang still separate urban district based on the activities. The roads which connecting between housing district and the office or traditional market become a heavy traffic jam in the morning and in the afternoon. If the new urban area of Palembang built more compact the traffic jam on the main road becomes lower than before, and that compact area can life all time of the day.

How about the citizen of Palembang? Is it any relationship between urban growth and the quality of life of Palembang citizen?

In this paper, we did not discuss in social-economic aspect. We try to assume the urban growth with BPS statistics data. Based on BPS data, we can see that expenditure and the minimum salary for workers in Palembang increased from 2010 until 2016 (see figure 16 and figure 17). We can make the hypothesis that urban growth have a correlation with a social-economic indicator at Palembang. There is another topic for a next research based on urban growth perspective. 


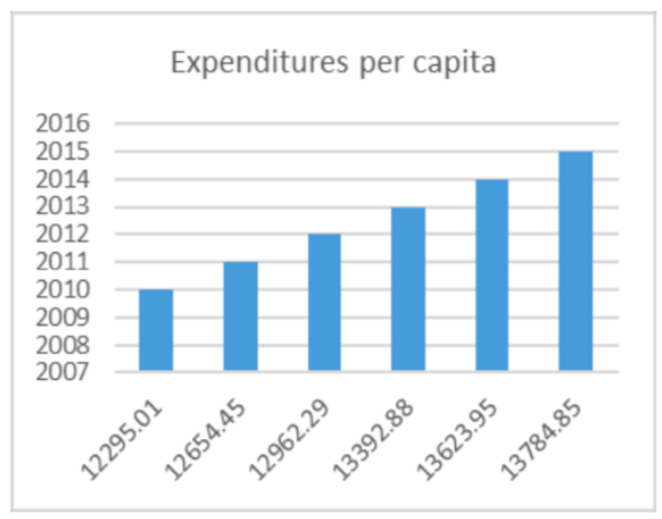

Figure 16. The expenditure of Palembang citizen

Source:

https://palembangkota.bps.go.id/subject/5/kons umsi-dan-pengeluaran.html\#subjekViewTab3

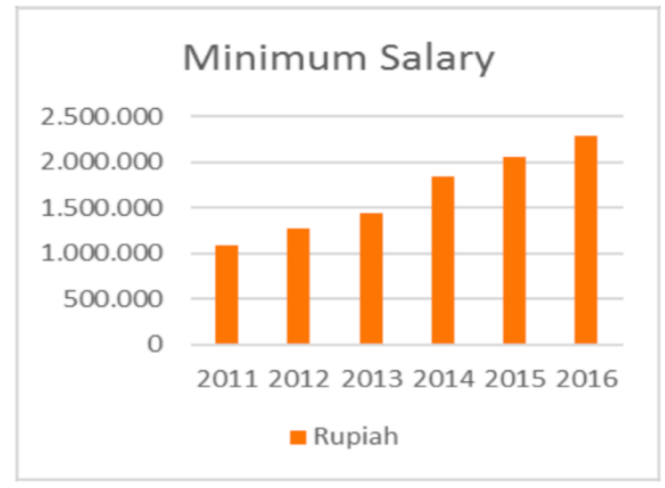

Figure 17. Minimum salary for Palembang workers

Source:

https://palembangkota.bps.go.id/subject/19/upa h--buruh.html\#subjekViewTab3

\section{Conclusion}

The urban form of Palembang change from linear city to radial city and finally become a multinuclear city. The main road in Palembang located in the Jalan Jenderal Sudirman, and the condition starting from the Japanese era (around 1940s) until now.

The development of infrastructure in Palembang is not based on the need of citizen, but based on the 'image of Palembang'. For the next research of urban growth, we must discuss with the citizen about their perception of Palembang growth, in social-economic perspective. Urban growth has an impact on citizen daily and the quality of their life. How about Palembang citizen? It is a next question for the next research.

The new facilities infrastructure in Palembang, called LRT, need to integrate with other modes of transportation, like bus or boats.

The compact city concepts maybe can solve the heavy traffic jam in Palembang.

\section{Acknowledgments}

Thank you to Adhika Atyanta to make maps based on remote sensing data analysis and GIS technic, and make a map of the transportation network.

Thank you to Setyo Nugroho for his previous study. His study, which added in this paper, is the part of his dissertation.

This paper is a part of our research with the title "Urban Growth and Sprawls with Remote Sensing Data Analysis". Thank you to Universitas Sriwijaya for giving research grant.

\section{References}

Aggarwal, S. (2004). Principles of remote sensing. Satellite Remote Sensing and GIS Applications in Agricultural Meteorology, 23-38. https://doi.org/doi:10.1201/b1015 5-2

Anderson, W. P., Kanaroglou, P. S., \& Miller, E. J. (1996). Urban form, energy, and the environment: a review of issues, evidence, and policy. Urban Studies, 33(1), $7-$ 35.

Bruinsma, F. R., Rienstra, S. A., \& Rietveld, P. (2013). Economic impacts of the construction of a transport corridor: A multi-level and multiapproach case study for the economic impacts of the 
construction of a transport corridor . A Multi-level and Multiapproach Case Study for the Construction of the $\mathrm{Al} \mathrm{Hi}$, (February), 37-41.

CDIA. (2011). Informal public transportation networks in three indonesian cities. Transportation, (June).

Danilo S. Furundzic; \& Furundzic, B. S. (2012). Infrastructure corridor as linear city. 1st International Conference on Architecture \& Urban Design Proceedings, (April), 721-728.

Jenks, M., Burton, E., \& Williams, K. (1996). The compact city: A sustainable urban form? https://doi.org/10.4324/97802033 62372

Neuman, M. (2012). Infrastructure planning for sustainable cities. Geographica Helvetica, 66(2), 100-107.

https://doi.org/10.5194/gh-66100-2011

Noftri, S., Faizal, M., \& Mohadi, R. (1999). Air quality analysis of $\mathrm{SO} 2, \mathrm{NO} 2$, and $\mathrm{CO}$ in Palembang city. Indonesian Journal of Fundamental and Applied Chemistry, (2), 58-61. https://doi.org/10.24845/ijfac.v2.i 4.58

Nugroho, S. (2012). Urban morphology at lowland environment in Palembang. 2nd Conveeesh \& 13th Senvar International ConferenceArchitecture.

Santun, D. I. M. (2001). Venesia dari Timur: Memaknai produksi dan reproduksi simbolik kota Palembang dari kolonial sampai pascakolonial. Yogyakarta: Ombak.

Trubka, R., Newman, P., \& Bilsborough, D. (2010). The costs of urban sprawl-infrastructure and transportation. Environment
Design Guide, (April), 1-6. Retrieved from http://espace.library.curtin.edu.au/ $\mathrm{R}$ ?func $=$ dbin_jump_full\&object_i $\mathrm{d}=160744$

Tufek-Memisevic, T., \& Stachura, E. W. A. (2015). A linear city development under. Residential Environment, 1882(14), 190-195.

Van Sevenhoven, J. I. (2015). Lukisan tentang ibu kota Palembang. Yogyakarta: Ombak.

Yenigun, K., \& Ecer, R. (2013). Overlay mapping trend analysis technique and its application in Euphrates Basin, Turkey. Meteorological Applications, 20(4), 427-438. https://doi.org/10.1002/met.1304 